\title{
Effects on lepidopteran herbivores of feeding on leaves of transgenic birch (Betula pendula) expressing the sugar beet chitinase IV gene
}

\author{
LIISA VIHERVUORI, PÄIVI LYYTIKÄINEN-SAARENMAA, JINRONG LU and HANNA-LEENA PASONEN \\ Department of Forest Sciences, University of Helsinki, FI-00014 Helsinki, Finland; e-mails: liisa.vihervuori@helsinki.fi; \\ paivi.lyytikainen-saarenmaa@helsinki.fi; jinrong.lu@helsinki.fi; hanna-leena.pasonen@mikkeli.fi
}

Key words. Lepidoptera, Lymantriidae, Orgyia antiqua, Notodontidae, Phalera bucephala, Betula pendula, silver birch, chitinase, herbivory simulation by leaf wounding, insect herbivore, nutritional indices, transgenic tree

\begin{abstract}
Transgenic lines of silver birch (Betula pendula) carrying the sugar beet chitinase IV gene were used to study the effects of the heterologous expression of a transgenic chitinase on the performance of lepidopteran herbivores. The effect of wounding the leaves of birch on the performance of lepidopteran larvae and the growth of trees was also studied. Larvae of Orgyia antiqua L., Lymantriidae, and Phalera bucephala L., Notodontidae, were separately fed on the leaves of transgenic and wild-type birch, and their performance measured using nutritional indices. The relative growth rate (RGR) of $O$. antiqua larvae fed transgenic leaves was significantly lower than that of larvae fed wild-type leaves. Furthermore, there is little evidence that transgenic chitinase affects survival but it was lowest for the group of larvae fed leaves with the highest expression of chitinase IV. Wounding did not have a significant effect on the performance of the larvae or on the growth of the branches of the trees. The growth of branches of particular transgenic lines, however, was significantly associated with tree line. The performance of $P$. bucephala larvae fed leaves of transgenic and wild-type birches did not differ. The leaves used in both experiments from transgenic trees were shorter than those from wild-type trees. Using transgenic birch expressing sugar beet chitinase IV to improve the resistance of birch to fungal diseases can have negative effects on $O$. antiqua larvae feeding on the leaves of these birches. $P$. bucephala, however, was not similarly affected, which indicates that these two ecologically similar lepidopteran species may differ in their response to transgenic chitinase.
\end{abstract}

\section{INTRODUCTION}

The effects of genetically modified (GM) trees on forest ecosystems are difficult to predict because of the long life cycles of trees and their complex interactions with other organisms (Brunner et al., 2007; Hjältén et al., 2007). Genetic modifications for improved disease resistance are of particular concern due to potentially harmful non-target effects (Myhr \& Traavik, 2002; Valenzuela et al., 2006). Birch lines carrying a chitinase IV gene from sugar beet under the CaMV 35S promoter, which increases their resistance to fungal diseases to varying degrees (Pappinen et al., 2002; Pasonen et al., 2004), were used to determine the effect chitinase $1 \mathrm{~V}$ has on the growth and performance of two lepidopteran species (Orgyia antiqua L. and Phalera bucephala L.) by feeding them on the leaves of transgenic birch. Both species belong to the subfamily Noctuoidea, feed on deciduous trees and shrubs and occur as larvae mid to late in the season (Seppänen, 1970). Outbreaks of O. antiqua sometimes occur, especially on bilberry (Vaccinium myrtillus L.) in Finland (Pohjola, 1947), whereas P. bucephala is less widely distributed and relatively common (Marttila et al., 1996). Previously, experiments on the resistance of GM trees to insect herbivores (Yang et al., 2003; Barbehenn et al., 2007; Wang et al., 2007) have used broadleaved trees with a genetically modified lignin biosynthesis pathway (Pilate et al., 2002; Tiimonen et al., 2005) with variable results. Previously we reported the effects of transgenic silver birch carrying the sugar beet chitinase IV gene on mycorrhizae (Pasonen et al., 2005, 2009) and soil organisms (Vauramo et al., 2006).

Chitinases are able to hydrolyze chitin, the main component in fungal cell walls, insect exoskeletons (Collinge et al., 1993) and the peritrophic membrane lining the gut of insects (Hegedus et al., 2009). Gene expression and production of chitinases in plants is induced by various factors, such as feeding by Lepidoptera and other insects (Krishnaveni et al., 1999; Walling, 2000; Major \& Constabel, 2006; Ralph et al., 2006). Function of insect chitinases are not thoroughly understood, but they do have a role during the larval stage of an insect's life cycle, especially during moulting (Merzendorfer \& Zimoch, 2003), and their enzymatic properties are very variable (Zhu et al., 2008). Heterologous expression of transgenic chitinase can affect the normal chitinase metabolism of insects that feed on them (Merzendorfer \& Zimoch, 2003) or impair the performance of insects by affecting the chitin lining of their guts (Brandt et al., 1978; Regev et al., 1996; Kramer \& Muthukrishnan, 1997).

So far only plants of the families Solanaceae and Brassicaceae producing transgenic chitinase have been fed to insects. Lepidoptera fed on transgenic plants expressing chitinase originating from a plant, insect or virus are adversely affected (Ding et al., 1998; Wang et al., 2005; Fiandra et al., 2010) to varying degrees (Gatehouse et al., 1997; Jouanin et al., 1998; Schuler et al., 1998). Transgenic tobacco expressing chitinase originating from poplar inhibit the development of Colorado potato beetle (Leptinotarsa decemlineata) (Lawrence \& Novak, 2006) 
and transgenic (viral) chitinase also reduces the damage caused by fungal pathogens and lepidopterous larvae (Corrado et al., 2008), which indicates that transgenic chitinases adversely affect lepidopterous larvae. However, the performance of aphids infesting transgenic plants expressing chitinase is improved (Saguez et al., 2005; Vihervuori et al., 2008). The differences between predictions and experimental results indicate there is uncertainty (Myhr \& Traavik, 2002) about the effects of transgenic chitinases on insects and variation among insects in their sensitivity to chitinases (Kramer \& Muthukrishnan, 1997; Jouanin et al., 1998; Schuler et al., 1998; Liu et al., 2006).

Performance of an insect herbivore is dependent on host plant quality (Awmack \& Leather, 2002) (including carbon, nitrogen, defensive metabolites and leaf properties like water content), which in turn is dependent on resistance reactions. Insect larvae prefer nitrogen and avoid harmful and poisonous chemicals (Scriber \& Slansky, 1981). The effect of food quality can be measured using nutritional indices like relative growth rate (RGR) and the efficiency of conversion of ingested food (ECI) (Price, 1997). To induce resistance reactions, wounding is often used, for example, by ripping or stapling leaves (Hjältén, 2004). A rapid induced reaction (RIR) may be induced in plants by wounding, which can in the same season result in a lower consumption by herbivores (Karban \& Myers, 1989). RIR in Betula is strongest on the wounded branch and has little effect on other branches (Wratten et al., 1984; Haukioja \& Hanhimäki, 1985). Though, induced responses of trees are less studied than those of herbaceous plants (Eyles et al., 2010), wounding is known to induce chitinase production in poplar leaves, which is a significant part of the woundinduced defence response of poplar (Christopher et al., 2004). It is suggested that there is a trade-off in the allocation of resources in plants to growth and defence (Herms \& Mattson, 1992). Little is known about resource allocation in transgenic plants (Coviella et al., 2002; Wu et al., 2011) or of the growth responses of transgenic plants, or that of their insect herbivores to the wounding of plants (Walling, 2000; Howe \& Schaller, 2008).

In this study, we hypothesized that constitutive expression of sugar beet chitinase IV gene in transgenic birch has negative effects on their lepidopterous herbivores. Although this transgene is targeted against fungal pathogens it may have a harmful non-target effect on Lepidoptera. Two different experiments were conducted with two ecologically similar species of moth. We tested the differences in the rapid induced resistance reactions (RIR) to wounding of transgenic and wild-type trees, and determined whether these reactions affect the performance of $O$. antiqua and the growth of the trees. Because the responses of plants to herbivory are influenced also by other biotic factors such as fungi (Stout et al., 2006), we suggest that the responses of trees genetically modified to be more resistant to fungal diseases and wild-type trees to insect feeding will vary.

\section{MATERIAL AND METHODS}

\section{Plant material}

The sugar beet chitinase IV gene was transferred to leaf explants of Finnish silver birch clone JR 1/4 (progeny of controlled cross E1970 $\times$ E1980). Sugar beet chitinase IV gene was introduced in the binary plasmid pBKL $4 \mathrm{~K} 4$ with enhanced $(4 \times)$ CaMV E35S promoter, nptII (neomysin phosphotransferase) gene under the control of nos promoter for kanamysin selection and uidA reporter gene coding for the enzyme $\beta$-glucuronidase (GUS). Pre-culturing of the plant tissue, co-culturing with Agrobacterium and selection of transgenic tissue are described in more detail by Pappinen et al. (2002). The transgenic and wildtype clones were grown in a greenhouse for 18 months before transferring to the field in October 2000. The field trial was established as a randomised block design consisting of 15 blocks, each containing one replicate of each type of plant. The height of the plants was approximately 1-2 $\mathrm{m}$ when harvested in autumn 2003. Plant material from the field (transgenic lines Chi 1 - Chi 15, of which Chi 1, 2, 10 and 12 were used together with the corresponding wild-type clone) was fed to larvae of $O$. antiqua (Table 1). The same transgenic lines were grown in the greenhouse and used later in 2007 in the feeding experiment with $P$. bucephala (of which lines Chi 1, 2, 3, 5, 7, 10, 13, 14 and the corresponding wild-type clone were used). The height of the trees was approximately $1-2 \mathrm{~m}$ when this study was carried out.

\section{Feeding experiment with $O$. antiqua \\ Northern blot}

The level of expression of the sugar beet chitinase IV in the leaves of the trees grown in the field trial was measured using Northern blot (Pasonen et al., 2004) and the transgenic lines classified as either high or low according to the level of the chitinase IV transcript. This classification of the transgenic lines was used in the feeding experiment with $O$. antiqua.

\section{Feeding experiment}

The egg batches of both species ( $O$. antiqua and $P$. bucephala) were stored at low temperature until required for the feeding tests. The larvae of $O$. antiqua and $P$. bucephala are the progeny of several females. Before the feeding tests, the larvae were fed non-transgenic birch leaves. The studies started when the larvae reached the second instar (a couple of days old) and finished when the first larvae started to pupate. The larvae that died at the beginning of the experiment were excluded. The adequacy of the food supply was checked daily and fresh, weighed food was added depending on the amount consumed.

$O$. antiqua larvae were collected from Vaarunvuori, Central Finland $\left(61^{\circ} 56^{\prime} \mathrm{N}, 25^{\circ} 43^{\prime} \mathrm{E}\right)$. The feeding test with $O$. antiqua was conducted in August 2003 (Table 1). Leaves from wounded and unwounded branches (6th and 7th from the top, respectively) of transgenic and control trees grown in the field were fed to the larvae. Unwounded and wounded leaf material was collected from different branches of the same trees. Each of the test units consisted of seven (boxes of) groups of larvae. Groups of 7 larvae were weighed and put into boxes (56 in total) with weighed leaves from one branch (Table 1). The larvae were reared for 7 days $\left(+20^{\circ} \mathrm{C}, 18 / 6 \mathrm{~h}\right)$ and weighed individually.

In both feeding experiments, the faeces and leaf material from the boxes were collected and separated, dried and weighed. Also the moisture content of 20 larvae was determined and used to convert fresh weight into dry weight (FW/DW-ratio). Growth and food consumption indices were calculated according to Waldbauer (1968) and Price (1997). The indices used were: 
TABLE 1. Experimental designs.

\begin{tabular}{|c|c|c|c|c|c|c|c|}
\hline \multirow[b]{2}{*}{ Experiment } & \multirow[b]{2}{*}{$\begin{array}{l}\text { Lepidopteran } \\
\text { species }\end{array}$} & \multirow[b]{2}{*}{$\begin{array}{l}\text { Transgenic } \\
\text { lines }\end{array}$} & \multirow[b]{2}{*}{$\begin{array}{l}\text { Classification of } \\
\text { the sugar beet chit } \\
\text { IV expression }\end{array}$} & \multirow{2}{*}{$\begin{array}{l}\text { Growing } \\
\text { environment } \\
\text { of the trees }\end{array}$} & \multirow[b]{2}{*}{ Treatment } & \multicolumn{2}{|c|}{ Replicates } \\
\hline & & & & & & $\begin{array}{c}\text { No of trees } \\
\text { per line per } \\
\text { treatment }\end{array}$ & $\begin{array}{l}\text { No of insect } \\
\text { groups per line } \\
\text { per treatment }\end{array}$ \\
\hline \multirow{6}{*}{ Feeding } & \multirow{3}{*}{ O. antiqua } & $10,12^{1}$ & High & $\mathrm{F}$ & $\mathrm{W} / \mathrm{U}$ & 7 & 7 \\
\hline & & $1,2^{1}$ & Low & F & $\mathrm{W} / \mathrm{U}$ & 7 & 7 \\
\hline & & Control $^{1}$ & No & $\mathrm{F}$ & $\mathrm{W} / \mathrm{U}$ & 7 & 7 \\
\hline & \multirow{3}{*}{ P. bucephala } & $1,2,10,14^{2}$ & High & $\mathrm{G}$ & No & 2 & 2 \\
\hline & & $3,5,7^{*}, 13^{2}$ & Low & G & No & 2 & 2 \\
\hline & & Control $^{2}$ & No & $\mathrm{G}$ & No & 4 & 2 \\
\hline \multirow{6}{*}{$\begin{array}{l}\text { Leaf length } \\
\text { and FW/DW }\end{array}$} & & $10,12^{1}$ & High & $\mathrm{F}$ & $\mathrm{W} / \mathrm{U}$ & 5 & \\
\hline & & $1,2^{1}$ & Low & F & $\mathrm{W} / \mathrm{U}$ & 5 & \\
\hline & & Control $^{1}$ & No & $\mathrm{F}$ & $\mathrm{W} / \mathrm{U}$ & 5 & \\
\hline & & $1,2,10,14^{2}$ & High & G & No & 5 & \\
\hline & & $3,5,7^{*}, 13^{2}$ & Low & G & No & 5 & \\
\hline & & Control $^{2}$ & No & G & No & 5 & \\
\hline \multirow{3}{*}{ Branch growth } & & $4,10,12,14^{1}$ & High & $\mathrm{F}$ & $\mathrm{W} / \mathrm{U}$ & $3-6$ & \\
\hline & & $1,2,5,7^{*}, 13^{1}$ & Low & F & $\mathrm{W} / \mathrm{U}$ & $5-9$ & \\
\hline & & Control $^{1}$ & No & $\mathrm{F}$ & $\mathrm{W} / \mathrm{U}$ & 7 & \\
\hline
\end{tabular}

${ }^{1}$ Northern blot, ${ }^{2}$ RT-PCR / enzyme assay; W - Wounding, U - Unwounded; F - Field, G - Greenhouse; * expression unknown in 2003, low in 2007.

RGR (relative growth rate, calculated as: [gained weight / (time / mean weight)], RCR [relative consumption rate, calculated as: (food consumed / time) / gained weight], ECD (efficiency of conversion of digested food, calculated as: gained weight / (ingested food - faeces) * $100 \%$, AD [approximate digestibility, calculated as: (ingested food - faeces) / ingested food * $100 \%$ ] and ECI (efficiency of conversion of ingested food, calculated as: gained weight / food ingested $* 100 \%$ ) and survival as percentage of larvae that survived.

\section{Wounding treatment}

Wounding treatment was used to (A) measure the effect of wounding on plant growth and (B) on larval growth $(O$. antiqua). Induced responses were studied by wounding eight field grown transgenic birch lines $(1,2,4,5,10,12,13$ and 14) with different levels of the sugar beet chitinase IV transcript (Table 1). Seven trees of each transgenic line and 14 of the wild type clone were used. All the leaves on a branch were wounded by tearing off the apical half of the lamina of each leaf on 27th May 2003 (about 2.5 months before the feeding tests were conducted on $O$. antiqua), before the leaves were fully grown. The control leaves were left intact. The 5th and 6th branches from the top of the tree were wounded. The 4 th and 7 th branches were used as unwounded controls. Branches 4 and 5 were used to measure the growth response of the branches and 6 and 7 for the insect feeding tests. To measure the growth response, the length of the branches was measured early in the season when some of the branches were wounded (27-28th May 2003) and again when the trees ceased growing (26th August 2003). The growth response was measured in terms of percentage increase in length of the branches between these two dates. Also the number of branches was counted in May and August.

\section{Leaf measurements}

In both feeding tests, fresh/dry weight ratio (FW/DW) of the leaves was determined and used to calculate the dry weight of consumed/ingested leaf material (oven-dried at $+80^{\circ} \mathrm{C}$, for 2 days, followed by 1 day in a desiccator). The lengths of the lamina of the leaves were also measured to determine the difference between leaves from wild type and transgenic trees.

\section{Feeding experiment with $P$. bucephala RT-PCR}

The sugar beet chitinase IV expression in the leaves of the greenhouse grown trees was studied by reverse transcriptionpolymerase chain reaction (RT-PCR). Total RNA was isolated from the birch leaf samples as described by Chang et al. (1993). $1 \mu \mathrm{g}$ of RNA was digested with DNase I (Finnzymes) and directly used for cDNA synthase by Superscript III reverse transcriptase (Invitrogen) with anchored poly $\mathrm{T}\left(\mathrm{T}_{20} \mathrm{VN}\right)$ according to the manufacturer's instructions. Primer pairs for chitinase IV were 5'-TGCCTCTAATTTATGTTGTAGCCG (forward) and 5'-CCCTTGGCATTGACGATAAC (reverse). The synthesized cDNA was amplified by PCR with DyNAzyme ${ }^{\mathrm{TM}}$ II DNA polymerase (Finnzymes, Espoo, Finland) in a reaction mixture containing $1 \times$ dynazyme buffer, $0.1 \mathrm{mM}$ of each dNTP, $0.5 \mu \mathrm{M}$ of each primer and $0.5 \mathrm{U}$ of dynazyme in a total volume of 25 $\mu 1$. The PCR program consisted of 28 cycles each of $30 \mathrm{~s}$ duration for template denaturation at $95^{\circ} \mathrm{C}, 40 \mathrm{~s}$ of primer annealing at $56^{\circ} \mathrm{C}$ and $50 \mathrm{~s}$ extension at $72^{\circ} \mathrm{C} .500 \mathrm{bp}$ chitinase PCR products were visualized on a $1 \%$ agarose gel. GeneRuler ${ }^{\mathrm{TM}} 1 \mathrm{~kb}$ Plus DNA Ladder (Fermentas GmbH, Germany) was used. Actin was used as the internal control using the primer 5'TGGTCAAGGCTGGGTTTGC (forward) and 5'-CTGACCCA TCCCAACCATGA (reverse) (Ruonala et al., 2006).

\section{Chitinase assay}

A fluorometric assay for endochitinase using 4-methylumbelliferyl- $\beta$-D-N,N'-triacetylchitotriose as a substrate (Bolar et al., 2000) was used to determine total endochitinase activity in the leaf samples from the greenhouse grown trees. A fluorometric assay was used to study the relationship between sugar beet chitinase IV expression and total endochtinase activity. The lines showing high chitinase IV expression were expected to show high total endochitinase activity. The leaves were collected from the same trees as the leaf material for the feeding test. $10-15 \mathrm{mg}$ of frozen leaf tissue was ground in assay buffer ( $1 \mathrm{ml}$ of $10 \%$ SDS, $1 \mathrm{ml}$ of $10 \%$ Triton X-100, $2 \mathrm{ml}$ of sodium EDTA $0.5 \mathrm{M}, 70 \mu 114.4 \mathrm{M}$ mercaptoethanol and $96 \mathrm{ml}$ of 100 $\mathrm{mM}$ sodium acetate buffer, $\mathrm{pH} 5.0$ ). $50 \mu \mathrm{l}$ of assay buffer was 
TABLE 2. Results of the two-way ANOVA of the effects on the feeding of $O$. antiqua of the level of expression of the transgene, determined by the Northern blot method, and wounding treatment (tearing off of apical half of a leaf).

\begin{tabular}{|c|c|c|c|c|c|}
\hline Variable & Source of variance & df & MS & $\mathrm{F}$ & $\mathrm{p}$ \\
\hline \multirow{4}{*}{ Food ingested, $\%$} & Exp level & 2 & 467.303 & 1.429 & 0.249 \\
\hline & Wounding treatment & 1 & 18.014 & 0.055 & 0.815 \\
\hline & Interaction & 2 & 405.722 & 1.241 & 0.296 \\
\hline & Error & 50 & 327.059 & & \\
\hline \multirow{4}{*}{ Food digested, \% } & Exp level & 2 & 54.314 & 1.809 & 0.174 \\
\hline & Wounding treatment & 1 & 0.024 & 0.001 & 0.980 \\
\hline & Interaction & 2 & 7.679 & 0.213 & 0.809 \\
\hline & Error & 50 & 36.097 & & \\
\hline \multirow{4}{*}{ RGR } & Exp level & 2 & 0.317 & 3.671 & $<0.05$ \\
\hline & Wounding treatment & 1 & 0.091 & 1.057 & 0.309 \\
\hline & Interaction & 2 & 0.103 & 1.190 & 0.313 \\
\hline & Error & 50 & 0.086 & & \\
\hline \multirow{4}{*}{$\mathrm{RCR}$} & Exp level & 2 & 5.132 & 0.212 & 0.810 \\
\hline & Wounding treatment & 1 & 4.449 & 0.184 & 0.670 \\
\hline & Interaction & 2 & 13.055 & 0.539 & 0.587 \\
\hline & Error & 50 & 24.232 & & \\
\hline \multirow{4}{*}{ ECD } & Exp level & 2 & 16.102 & 1.459 & 0.242 \\
\hline & Wounding treatment & 1 & 6.724 & 0.609 & 0.439 \\
\hline & Interaction & 2 & 3.434 & 0.311 & 0.734 \\
\hline & Error & 50 & 11.036 & & \\
\hline \multirow{4}{*}{$\mathrm{AD}$} & Exp level & 2 & 167.431 & 0.912 & 0.408 \\
\hline & Wounding treatment & 1 & 0.321 & 0.002 & 0.967 \\
\hline & Interaction & 2 & 605.698 & 3.300 & $<0.05$ \\
\hline & Error & 50 & 183.534 & & \\
\hline \multirow{4}{*}{ ECI } & Exp level & 2 & 12035.420 & 1.599 & 0.212 \\
\hline & Wounding treatment & 1 & 3148.064 & 0.418 & 0.521 \\
\hline & Interaction & 2 & 2683.801 & 0.356 & 0.702 \\
\hline & Error & 50 & 7529.163 & & \\
\hline \multirow{4}{*}{ Survival } & Exp level & 2 & 976.650 & 2.204 & 0.121 \\
\hline & Wounding treatment & 1 & 52.461 & 0.118 & 0.732 \\
\hline & Interaction & 2 & 123.910 & 0.280 & 0.757 \\
\hline & Error & 50 & 443.135 & & \\
\hline
\end{tabular}

used per mg of leaf tissue. $100 \mu \mathrm{l}$ ground extract was mixed with $40 \mu \mathrm{l}$ of $4-\mathrm{MU}-\beta-\mathrm{D}-\mathrm{N}, \mathrm{N}^{\prime}$-triacetylchitotriose substrate (1 $\mathrm{mg}$ of substrate dissolved in $3.5 \mathrm{ml}$ of $100 \mathrm{mM}$ sodium acetate buffer, $\mathrm{pH}$ 5.0). The reaction was stopped either after $60 \mathrm{~min}$ or $90 \mathrm{~min}$ using $1.9 \mathrm{ml}$ of $0.2 \mathrm{M}$ sodium carbonate. Fluorescence was determined at 360/460 (excitation/emission) using a Bio-Rad Versafluor fluorometer. Fluorecence of known concentrations of 4-MU was used to plot a standard curve to determine total activity of endochitinase. The amount of protein was determined using Bio-Rad Bradford dye-binding protein assay. The results are expressed as $\mathrm{nM} \mathrm{MU} / \mathrm{min} / \mu \mathrm{g}$ protein.

\section{Feeding experiment}

P. bucephala larvae feeding on Betula pendula were collected from Vihti, Southern Finland $\left(60^{\circ} 28^{\prime} \mathrm{N}, 24^{\circ} 26^{\prime} \mathrm{E}\right)$. The feeding test with P. bucephala was conducted in August 2007 using greenhouse grown plant material (Table 1). The leaves from the 5th, 6th and 7th branch from the top of the birches were fed to larvae of $P$. bucephala. There were two (boxes of) groups of larvae in each of the test units. Groups of 6 larvae were weighed and put into boxes (20 in total) with weighed leaves from one tree. The larvae were reared for 10 days in a growing chamber (for details, see Feeding experiment with $O$. antiqua).

\section{Statistical analyses}

To study enzyme activity a one-way ANOVA (and Dunnet's test) was used. To study the effects of the level of expression of sugar beet chitinase IV and wounding treatment on the feeding performance and nutritional indices of larvae, and growth response (wounding treatment) of the trees, fixed-effects 2-way ANOVA was used (only with $O$. antiqua). One-way ANOVA was used to study the effects of the level of total endochitinase activity on the nutritional indices of the larvae of $P$. bucephala. One-way ANOVA was used to study the leaf measurements. Kruskal-Wallis test was used to test the differences among the transgenic lines and Mann-Whitney test for pairwise comparisons between the transgenic lines or expression groups (high vs. low) and the corresponding control when non-paramentric testing was needed. SPSS 16 statistical package for Windows was used for calculating all the statistics in both feeding experiments. Pearson correlation was used to study correlations between leaf and larval characteristics. 

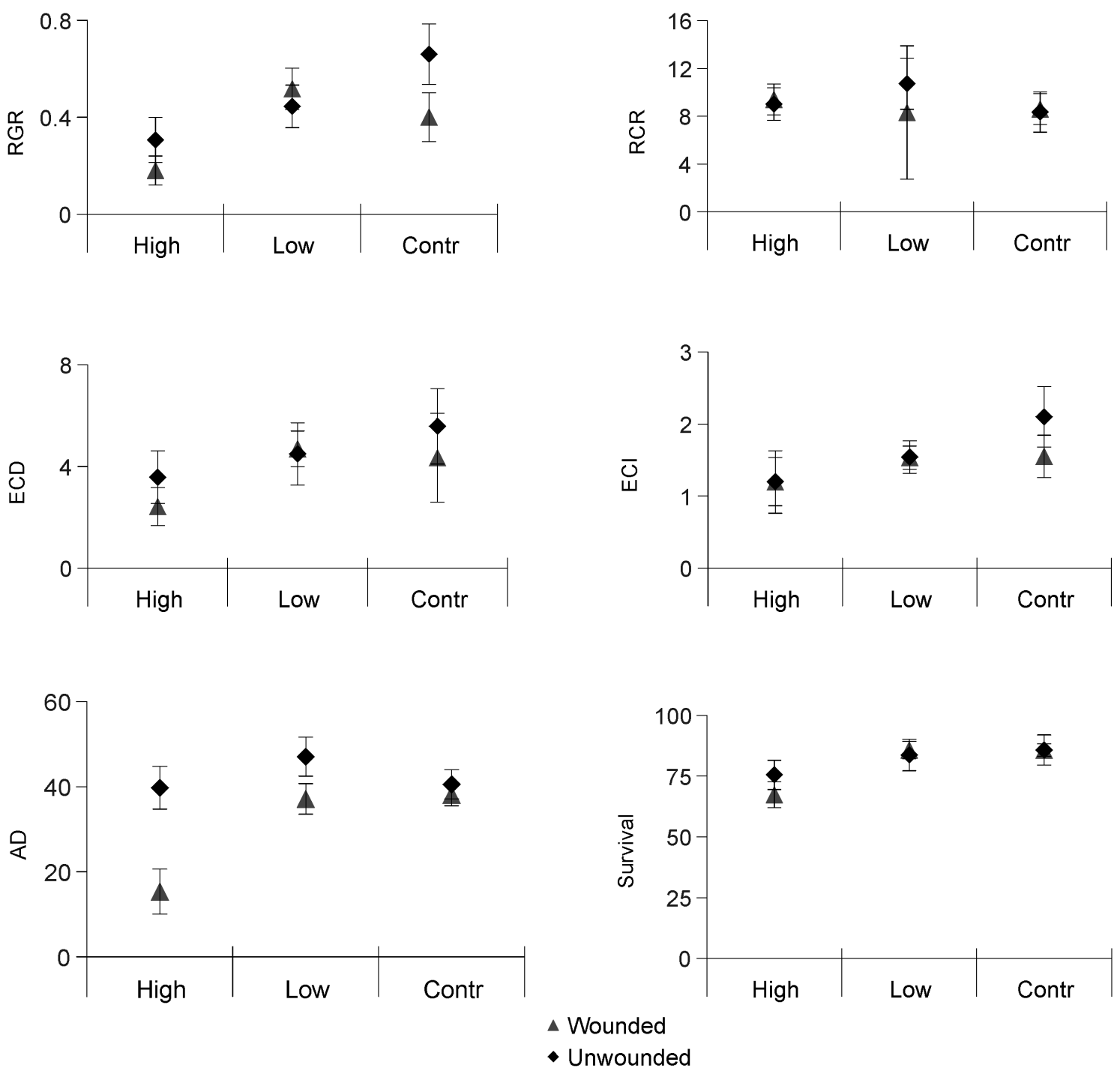

Fig. 1. Variation in the nutritional indices of larvae of $O$. antiqua fed on the leaves of different lines of birch (high / low transgene expression and the non-transgenic control), which were either wounded or not (wounded, unwounded) ( \pm SE).

\section{RESULTS}

\section{Field study}

Feeding experiment with $O$. antiqua

The transgenic lines were classified into two groups, high and low expression of sugar beet chitinase IV, based on the results of the Northern blot analysis (Pasonen et al., 2004) (Table 1). The level of transgene expression had a significant effect on the relative growth rate (RGR). Wounding did not affect any of the parameters studied (Table 2). The nutritional indices of the larvae fed unwounded leaves were generally higher than those fed leaves from wounded branches (Fig. 1). There was more variation in the results for wounded than unwounded leaves.

Although not significant so, survival and many of the nutritional indices (RGR, ECD, ECI and AD) were lowest for the larvae fed leaves with a high expression of sugar beet chitinase IV (Fig. 1). Transgenic line 12 was the worst in terms of many of the parameters measured in the O. antiqua experiment. Larvae fed on leaves from line 12 had the lowest values of RGR, ECD, ECI and survival compared with other lines and the control, especially the consumption of wounded leaves. RGR of larvae fed on line 12 was significantly lower than that of the control (pooled group $\mathrm{U}=7.00, \mathrm{Z}=-2.231, \mathrm{p}<0.05$ ).

Growth response of birch branches to wounding

The growth of the branches was significantly associated with tree line $(\mathrm{F}=2.148, \mathrm{df}=9, \mathrm{p}<0.05)$ but not wounding (data is not shown). There was no interaction between the transgenic lines and the treatment indicating that all the transgenic lines responded in a similar way to wounding. Also the level of transgene expression had no influence on the growth of the branches, either wounded, unwounded or pooled branches. The growth response of the transgenic lines to wounding did not differ significantly from that of the control plants or between transgenic lines. In spite of the fact that the transgenic lines showed a slightly greater growth response to wounding than control trees, transgenic lines had both lower absolute and relative branch growths than the control, when 


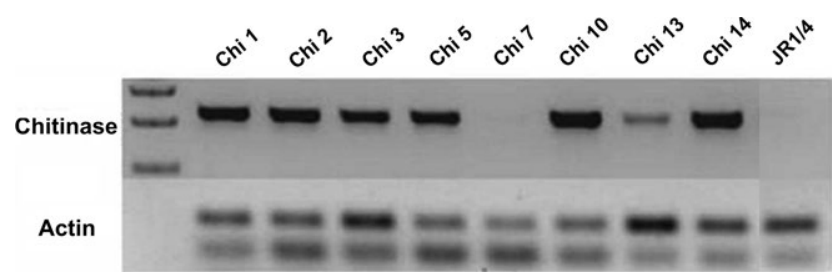

Fig. 2. Sugar beet chitinase IV transcript accumulation in the leaves of the birch lines measured using RT-PCR with gene specific primers. Actin was used as an internal control. Leaves of line Chi 1 to Chi 14 were fed to larvae of $P$. bucephala and JR1/4 is the non-transgenic control for the chitinase transgenic lines grown in the greenhouse.

the results for the wounded and unwounded branches were pooled. The relative branch growth of one transgenic line (7) was significantly lower than that of the control (pooled group $\mathrm{U}=26.000, \mathrm{Z}=-2.255, \mathrm{p}<0.05$ ). Relative branch growth did not differ between the transgenic lines in either the wounded or unwounded group.

\section{Leaf measurements}

The leaves of transgenic birches were significantly shorter than those of the control plants in both feeding experiments, when all the results for the transgenic lines were compared with the control. In the study with $O$. antiqua, transgenic lines 2 and 10 had lower water content ratios (FW/DW) compared with the control plants (U $=3685, \mathrm{p}<0.001 ; \mathrm{U}=249,000, \mathrm{p}<0.01$, respectively). The leaves were shorter in most of the transgenic lines (1, 10 and 12) than in the control plants $(\mathrm{p}<0.01, \mathrm{p}<0.001$, $\mathrm{p}<0.001$, respectively). The FW/DW did not differ between wounded and unwounded leaves. The RGR of O. antiqua larvae was correlated with leaf length $(0.973$, $\mathrm{p}<0.01)$. None of the other insect parameters studied were correlated with the leaf water content ratio.

TABLE 3. Total endochitinase activity of the chitinase transgenic lines and non-transgenic control determined using a fluorometric assay (fold change $=$ increase in total endochitinase activity compared to the control).

\begin{tabular}{lccc}
\hline \multirow{2}{*}{ Line } & \multicolumn{3}{c}{ Chitinase activity $(\mathrm{nM} \mathrm{MU} / \mathrm{min} / \mu \mathrm{g}$ protein) } \\
\cline { 2 - 4 } & Mean & Std & Fold change \\
\hline Chi 1 & 0.094 & 0.004 & 2.00 \\
Chi 2 & 0.096 & 0.037 & 2.04 \\
Chi 3 & 0.078 & 0.037 & 1.66 \\
Chi 5 & 0.047 & 0.013 & - \\
Chi 7 & 0.090 & 0.035 & 1.92 \\
Chi 10 & 0.116 & 0.019 & 2.47 \\
Chi 13 & 0.034 & 0.003 & - \\
Chi 14 & $0.173 *$ & 0.076 & 3.68 \\
Control & 0.047 & 0.016 & \\
\hline
\end{tabular}

*Significant difference $(\mathrm{p}<0.001)$ between the transgenic line and the non-transgenic control in chitinase activity (Dunnett's test).
TABLE 4. Results of the one-way ANOVA of the effects on feeding and growth of larvae of $P$. bucephala that were fed leaves with different levels of total endochitinase activity.

\begin{tabular}{lcccc}
\hline Variable & $\mathrm{df}$ & $\mathrm{MS}$ & $\mathrm{F}$ & $\mathrm{p}$ \\
\hline Ingested food, \% & 2 & 339.977 & 1.255 & 0.315 \\
Error & 16 & 1150886.7 & & \\
AD/Digested food, (same) & 2 & 120.953 & 0.509 & 0.612 \\
Error & 16 & 3566.953 & & \\
RGR & 2 & 0.000 & 0.028 & 0.973 \\
Error & 16 & 0.005 & & \\
RCR & 2 & 0.009 & 0.547 & 0.591 \\
Error & 16 & 0.249 & & \\
ECD & 2 & 1060.973 & 2.094 & 0.063 \\
Error & 16 & 9215.335 & & \\
ECI & 2 & 8.074 & 1.147 & 0.346 \\
Error & 16 & 114.692 & & \\
Survival & 2 & 573.030 & 1.847 & 0.194 \\
Error & 16 & 5490.196 & & \\
\hline
\end{tabular}

\section{Greenhouse study}

Chitinase IV expression and enzyme activity

Sugar beet chitinase IV expression was examined using the RT-PCR method and leaves of greenhouse grown birch lines. All lines studied were confirmed to be transgenic and expressing the chitinase IV gene (only line 7 showed very weak transgene expression) (Fig. 2). Total endochitinase activity in most of the transgenic lines was only slightly higher or equal to that of the non-transgenic control. Transgenic line 14 showed a significantly ( $\mathrm{p}<$ $0.05)$ higher and line 10 almost significantly higher total endochitinase activity than the control (Tables 1 and 3). The transgenic lines tested were classified into two groups (high or low total endochitinase activity) based on the results of the chitinase assay. The increase in total endochitinase activity was assumed to be due to the functioning of the chitinase IV transgene. If the increase in total endochitinase activity was equal to or more than twice that of the non-transgenic control, the transgenic line was classified in the "high endochitinase activity" group. Four lines (1, 2, 10 and 14) were classified in this group (Tables 1 and 3 ).

Because the classification of the lines was based on their comparative expression, based on RT-PCR or Northern blot, those lines with moderate expression were classified into "high" or "low" groups depending on their level of expression relative to the other lines within the same experiment. Hence lines 1 and 2 were classified into different groups in the Northern blot and RT-PCR analyses.

\section{Feeding experiment with $P$. bucephala}

The level of total endochitinase activity did not have a significant effect on any of the parameters of $P$. bucephala measured (Table 4), i.e. there were no differences in the nutritional indices or feeding performance of larvae fed leaves with a high or low total endochitinase activity and on control leaves. Nevertheless, the propor- 
tion of leaves consumed and digested by larvae was slightly lower for those fed leaves with high endochitinase activity than those fed leaves with low levels of endochitinase activity or those from control plants (data not shown).

\section{Leaf measurements}

In the study with $P$. bucephala, lines 1 and 10 had higher FW/DW than the control plants ( $<<0.001, \mathrm{p} \leq$ 0.001 , respectively). The leaves were significantly shorter in three of the lines (lines 3, 5 and 10) compared to those of the control plants $(\mathrm{p}<0.01, \mathrm{p}<0.01, \mathrm{p}<0.001$, respectively). Leaf properties, like length and water content, were correlated with larval performance, such as feeding indices and proportions of ingested and digested food. Most notably, food ingested and digested, RGR, $\mathrm{AD}, \mathrm{ECI}$ and survival were correlated with leaf water content, with both positive and negative correlations recorded $(-0.842, \mathrm{p}<0.01 ; 0.707, \mathrm{p}<0.05 ;-0.861, \mathrm{p}<$ $0.01 ; 0.887, \mathrm{p}<0.01 ; 0.928 \mathrm{p}<0.001 ;-0.855, \mathrm{p}<0.01$, respectively). Leaf length did not correlate with any of the parameters studied.

\section{DISCUSSION AND CONCLUSIONS}

Survival and many of the nutritional indices (RGR, $\mathrm{ECD}$, ECI and $\mathrm{AD}$ ) of $O$. antiqua larvae fed leaves showing high sugar beet chitinase IV expression were among the lowest recorded. This indicates that the conversion of absorbed nutrients into caterpillar biomass was the lowest for those $O$. antiqua larvae fed leaves with a high chitinase expression. Some earlier studies show that transgenic chitinase may have a strong effect on insect growth and development (Regev et al., 1996; Lawrence \& Novak, 2006; Corrado et al., 2008). The transgenic chitinase may affect lepidopteran larvae directly by damaging the peritrophic membrane (PM) lining the gut of insects (Kramer \& Muthukrishnan, 1997; Lawrence \& Novak, 2006). Insect growth and development is very dependent on their capability of quickly remodelling the chitinous structures in peritrophic matrices just before moulting. Thus, chemical compounds that interfere with chitin metabolism may affect insects negatively (Kramer \& Muthukrishnan, 1997; Merzendorfer \& Zimoch, 2003). Viral chitinase fed to lepidopteran larvae causes large lesions in the peritrophic membrane (Rao et al., 2004), which greatly increases its permeability (Fiandra et al., 2010). The effect on the larvae is a reduction in the efficiency with which food is converted to body mass. This is reflected in feeding indices like ECI and ECD, as recorded for $O$. antiqua fed leaves from line 12 . However, sugar beet chitinase IV did not affect the performance of $P$. bucephala, which indicates that the response of a lepidopteran herbivore to transgenic chitinase is likely to depend on the species. Feeding $P$. bucephala on water stressed $B$. pendula leaves results in higher ECI values, which indicate improved fitness (Thomas \& Hodkinson, 1991). It seems that the chitinase transgene had less of an effect on $P$. bucephala larvae than water stress. Whether the variation in the sensitivity of different lepidopteran species to the same chitinase is due to differences in the structure or composition of their peritrophic membranes needs further study.

The differences in the response of larvae of $O$. antiqua fed wounded or unwounded leaves indicate that birch show a rapid induced reaction (RIR) to wounding and the survival of larvae fed on wounded leaves with high chitinase IV expression was lower than on unwounded leaves. The RIR might have been strongest immediately after wounding, but may remain for weeks or even months as shown by Wratten et al. (1984). Because wounding did not result in a change in the water content of the leaves, the lower consumption rates may be linked to a change in the $\mathrm{C} / \mathrm{N}$ balance of the leaves (Herms \& Mattson, 1992). In earlier studies, the effects of wounding were variable (Nykänen \& Koricheva, 2004). The larvae of Spodoptera littoralis Boisduval and $O$. antiqua consume fewer wounded than unwounded leaves (Wratten et al., 1984). In addition, Spodoptera litura Fabricius, which is a generalist, prefers unwounded leaves, whereas the specialist Plutella xylostella L. prefers wounded leaves (Mathur et al., 2011). The effect of wounding on larval performance depends on the species of insect studied (Hartley \& Lawton, 1987; Haukioja, 1990). A strong induced response is recorded for early season herbivores on birch (Hanhimäki, 1989) or species that are more specialized on birch, because specialists may react to small changes in plant quality (Reavey, 1991). Nevertheless, artificial wounding differs from natural damage (Hjältén, 2004) and the results so obtained cannot be directly compared with natural consumption.

The growth response of the branches to wounding was similar in the transgenic and non-transgenic control plants. The chitinase IV transgene did not have a significant effect on branch growth, but there was a tendency of most transgenic lines to show a lowered percentage growth. In other studies, wounding had a more negative effect on tree growth than recorded in our study (Hjältén et al., 1993; Nykänen \& Koricheva, 2004). Our results might be explained by either the amount of leaf biomass removed was too small or the intensity and duration of induced responses are variable (Haukioja, 1990).

Transgenic status did not have an effect on the FW/DW of the leaves and the FW/DW ratio of the leaves was not associated with the level of expression of sugar beet chitinase IV, but seemed to be associated with differences in the performance of $P$. bucephala larvae. Leaf moisture is an important trait affecting the performance of herbivorous insects on birch (Haukioja, 2003). Performance of $O$. antiqua was associated with the length of the leaves, which were shortest on the lines with highest expression of chitinase IV. Leaf length is an important factor determining the feeding preference of insects on birch (Suomela et al., 1995). In addition, transgenic poplar trees bear shorter leaves than wild type control trees (Poupin \& Arce-Johnson, 2005). The influence of chitinase IV transgene on plant growth and morphological features may be pleiotropic effect of the transgene (Pasonen et al., 2008).

Silver birch has endogeneous chitinase genes and altogether thirteen partial chitinase sequences, with an 
approximate length of $600 \mathrm{bp}$, are recorded in silver birch EST libraries (Aalto \& Palva, unpubl. data). These chitinase sequences belong to five chitinase classes and some of them are very similar in structure to the sugar beet chilV gene (Lohtander et al., 2008). Hence, the constitutive expression of an exogeneous chitinase gene could disturb the functioning of the silver birch's own endogeneous chitinase genes, which are likely to have functions other than pathogenesis (Griffith \& Yaish, 2004; Fossdal et al., 2007; Distefano et al., 2008). This could also explain the low increase in total endochitinase activity recorded in the plant material used in this study.

To conclude, our results show that the heterologous expression of sugar beet chitinase IV in transgenic silver birch can have negative effects on the performance of $O$. antiqua larvae feeding on the leaves of transgenic birch. Especially for unwounded leaves, there is a clear increasing trend in indices like RGR, ECD and ECI, when the larvae are fed leaves from the lines with high chitinase expression and the wild-type control-groups. The chitinase IV transgene had no effect on the larvae of $P$. bucephala, which indicate that Lepidoptera are not all, equally affected by transgenic chitinase. The effect of transgenic chitinases on lepidopteran larvae can be direct, if they hydrolyse the chitin in the gut of larvae or indirect when they affect the traits of leaves like moisture.

ACKNOWLEDGEMENTS. The authors would like to thank the staff of the University of Helsinki for helping with the growing trials and gene tests. The eggs of the Orgyia antiqua were kindly provided by J. Mappes (Univ. of Jyväskylä) and those of Phalera bucephala by J. Päivänen (Univ. of Helsinki). The authors would like to thank Finnish Cultural Foundation, Niemi Foundation, Suomalainen Konkordia-liitto and University of Helsinki Funds for funding this project.

\section{REFERENCES}

Awmack C.S. \& Leather S.R. 2002: Host plant quality and fecundity in herbivorous insects. - Annu. Rev. Entomol. 47: $817-844$.

Barbehenn R.V., Jones C.P., Yip L., Tran L. \& Constabel C.P. 2007: Limited impact of elevated levels of polyphenol oxidase on tree-feeding caterpillars: assessing individual plant defenses with transgenic poplar. - Oecologia 154: 129-140.

Bolar J.P., Norelli J.L., Wong K.-W., Hayes C.K., Harman G.E. \& Aldwinckle H.S. 2000: Expression of endochitinase from Trichoderma harzianum in transgenic apple increases resistance to apple scab and reduces vigor. - Phytopathology 90: $72-77$.

Brandt C.B., Adang M.J. \& Spence K.D. 1978: The peritrophic membrane: Ultrastructural analysis and function as a mechanical barrier to microbial infection in Orgyia pseudotsugata. - J. Invert. Pathol. 32: 12-24.

Brunner A.M., Li J., DiFazio S.P., Shevchenk O., Montgomery B.E., Mohamed R., Wei H., Ma C., Elias A.A., VanWormer K. \& Strauss S.H. 2007: Genetic containment of forest plantations. - Tree Genet. Genomes 3: 75-100.

Chang S., Puryear J. \& Cairney J. 1993: A simple and efficient method for isolating RNA from pine trees. - Plant Mol. Biol. Rep. 11: 113-116.

Christopher M.E., Miranda M., Major I.T. \& Constabel C.P. 2004: Gene expression profiling of systemically woundinduced defenses in hybrid poplar. - Planta 219: 936-947.
Collinge D.B., Kragh K.M., Mikkelsen J.D., Nielsen K.K., Rasmussen U. \& VAD K. 1993: Plant chitinases. - Plant J. 3: $31-40$.

Corrado G., Arciello S., Fanti P., Fiandra L., Garonna A., Digilio M.C., Lorito M., Giordana B., Pennacchio F. \& Rao R. 2008: The Chitinase A from the baculovirus AcMNPV enhances resistance to both fungi and herbivorous pests in tobacco. - Transgenic Res. 17: 557-571.

Coviella C.E., Stipanovic R.D. \& Trumble J.T. 2002: Plant allocation to defensive compounds: interactions between elevated $\mathrm{CO}_{2}$ and nitrogen in transgenic cotton plants. - J. Exp. Bot. 53: 323-331.

Ding X., Gopalakrishnan B., Johnson L.B., White F.F., Wang X., Morgan T.D., Kramer K.J. \& Muthukrishnan S. 1998: Insect resistance of transgenic tobacco expressing an insect chitinase gene. - Transgenic Res. 7: 77-84.

Distefano G., La Malfa S., Vitale A., Lorito M., Deng Z. \& Gentile A. 2008: Defence-related gene expression in transgenic lemon plants producing an antimicrobial Trichoderma harzianum endochitinase during fungal infection. - Transgenic Res. 17: 873-879.

Eyles A., Bonello P., Ganley R. \& Mohammed C. 2010: Induced resistance to pests and pathogens in trees. - New Phytol. 185: 893-908.

Fiandra L., Terracciano I., Fanti P., Garonna A., Ferracane L., Fogliano V., Casartelli M., Giordana B., Rao R. \& PenNACCHIO F. 2010: A viral chitinase enhances oral activity of TMOF. - Insect Biochem. Mol. Biol. 40: 533-540.

Fossdal C.G., Nagy N.E., Johnsen Ø. \& Dalen L.S. 2007: Local and systemic stress responses in Norway spruce: Similarities in gene expression between a compatible pathogen interaction and drought stress. - Physiol. Mol. Plant Pathol. 70: $161-173$.

Gatehouse A.M.R., Davison G.M., Newell C.A., Merryweather A., Hamilton W.D.O., Burgess E.P.J., Gilbert R.J.C. \& Gatehouse J.A. 1997: Transgenic potato plants with enhanced resistance to the tomato moth, Lacanobia oleracea: growth room trials. - Mol. Breeding 3: 49-63.

GRIFFITH M. \& YAISH M.W.F. 2004: Antifreeze proteins in overwintering plants: a tale of two activities. Trends Plant Sci. 9: 399-405.

HANHIMÄKI S. 1989: Induced resistance in mountain birch: defence against leaf-chewing insect guild and herbivore competition. - Oecologia 81: 242-248.

HartLey S.E. \& LawTON J.H. 1987: Effects of different types of damage on the chemistry of birch foliage, and the responses of birch feeding insects. - Oecologia 74: 432-437.

Haukioja E. 1990: Induction of defenses in trees. - Annu. Rev. Entomol. 36: 25-42.

Haukioja E. 2003: Putting the insect into the birch-insect interaction. - Oecologia 136: 161-168.

Haukioja E. \& HanHimäKI S. 1985: Rapid wound-induced resistance in white birch (Betula pubescens) foliage to the geometrid Epirrita autumnata: a comparison of trees and moths within and outside the outbreak range of the moth. - Oecologia 65: 223-228.

Hegedus D., Erlandson M., Gillott C. \& Toprak U. 2009: New insights into peritrophic matrix synthesis, architecture, and function. - Annu. Rev. Entomol. 54: 285-302.

Herms D.A. \& Mattson W.J. 1992: The dilemma of plants: to grow or defend. - Q. Rev. Biol. 67: 283-335.

HJÄLTÉN J. 2004: Simulating herbivory: problems and possibilities. In Weisser W.W. \& Siemann E. (eds): Insects and Ecosystem Function. Ecological Studies 173. Springer, Berlin, pp. 243-255. 
HJäLtÉn J., DANell K. \& ERICSON L. 1993: Effects of simulated herbivory and intraspecific competition on the compensatory ability of birches. - Ecology 74: 1136-1142.

Huältén J., Lindau A., Wennström A., Blomberg P., Witzell J., HURRY V. \& ERICSON L. 2007: Unintentional changes of defence traits in GM trees can influence plant-herbivore interactions. - Basic Appl. Ecol. 8: 434-443.

Howe G.A. \& Schaller A. 2008: Direct defenses in plants and their induction by wounding and insect herbivores. In Schaller A. (ed.): Induced Plant Resistance to Herbivory. Springer, New York, pp. 7-29.

Jouanin L., Bonadé-Bottino M., Girard C., Morrot G. \& Giband M. 1998: Transgenic plants for insect resistance. Plant Sci. 131: 1-11.

Karban R. \& Myers J.H. 1989: Induced plant responses to herbivory. Annu. Rev. Ecol. Syst. 20: 331-348.

KRAMER K.J. \& MUTHUKRISHNAN S. 1997: Insect chitinases: molecular biology and potential use as biopesticides. - Insect Biochem. Mol. Biol. 27: 887-900.

Krishnaveni S., Muthukrishnan S., Liang G.H., Wilde G. \& MANiCKAM A. 1999: Induction of chitinases and $\beta$-1,3-glucanases in resistant and susceptible cultivars of sorghum in response to insect attack, fungal infection and wounding. - Plant Sci. 144: 9-16.

LAWRENCE S.D. \& NovaK N.G. 2006: Expression of poplar chitinase in tomato leads to inhibition of development in Colorado potato beetle. - Biotechnol. Lett. 28: 593-599.

LiU S., Li H., Sivakumar S. \& Bonning B.C. 2006: Virusderived genes for insect-resistant transgenic plants. - Adv. Virus Res. 68: 427-257.

Lohtander K., Pasonen H.L., Aalto M.K., Palva T., Pappinen A. \& RikKinen J. 2008: Phylogeny of chitinases and its implications for estimating horizontal gene transfer from chitinasetransgenic silver birch (Betula pendula). - Environ. Biosafety Res. 7: 227-239.

Major I.T. \& Constabel C.P. 2006: Molecular analysis of poplar defense against herbivory: comparison of wound- and insect elicitor-induced gene expression. - New Phytol. 172: $617-635$.

Marttila O., SaArinen K., Haahtela M. \& Pajari M. 1996: Suomen kiitäjät ja kehrääjät. [Hawkmoths, Bombycoids, Notodontids, Lymantriids and Arctiids of Finland.] Kirjayhtymä, Porvoo, 384 pp. [in Finnish].

Mathur V., Ganta S., Raaijmakers C.E., Reddy A.S., Vet L.E.M. \& VAN DAM N.M. 2011: Temporal dynamics of herbivore-induced responses in Brassica juncea and their effect on generalist and specialist herbivores. - Entomol. Exp. Appl. 139: 215-225.

Merzendorfer H. \& Zimoch L. 2003: Chitin metabolism in insects: structure, function and regulation of chitin synthases and chitinases. - J. Exp. Biol. 206: 4393-4412.

MYhr A.I. \& TraAviK T. 2002: The precautionary principle: Scientific uncertainty and omitted research in the context of GMO use and release. - J. Agr. Environ. Ethics 15: 73-86.

NyKäNEn H. \& Koricheva J. 2004: Damage-induced changes in woody plants and their effects on insect herbivore performance: a meta-analysis. - Oikos 104: 247-268.

Pappinen A., Degefu Y., Syrjälä L., Keinonen K. \& von WeisSENBERG K. 2002: Transgenic silver birch (Betula pendula) expressing sugarbeet chitinase 4 shows enhanced resistance to Pyrenopeziza betulicola. - Plant Cell Rep. 20: 1046-1051.

Pasonen H.-L., Seppänen S.-K., Degefu Y., RytKönen A., von Weissenberg K. \& PAPPINEN A. 2004: Field performance of chitinase transgenic silver birches (Betula pendula): resis- tance to fungal diseases. - Theor. Appl. Genet. 109: 562-570.

Pasonen H.-L., Degefu Y., Brumós J., Lohtander K., Pappinen A., Timonen S. \& Seppënen S.-K. 2005: Transgenic Betula pendula expressing sugar beet chitinase IV forms normal ectomycorrhizae with Paxillus involutus in vitro. - Scand. J. Forest Res. 20: 385-392.

Pasonen H.-L., Vihervuori L., Seppänen S.-K., LyytikäInenSaArenmaa P., Ylioja T., von Weissenberg K. \& Pappinen A. 2008: Field performance of chitinase transgenic silver birch (Betula pendula Roth): growth and adaptive traits. - Trees Struct. Funct. 22: 413-421.

Pasonen H.-L., Lu J., Niskanen A.M., Seppänen S.-K., Rytkönen A., Raunio J., Pappinen A., Kasanen R. \& Timonen S. 2009: Effects of sugar beet chitinase IV on root-associated fungal community of transgenic silver birch in a field trial. Planta 230: 973-983.

Pilate G., Guiney E., Holt K., Petit-Conil M., Lapierre C., Leplé J.-C., Pollet B., Mila I., Webster E.A., Marstorp H.G., Hopkins D.W., Jouanin L., Boerjan W., Schuch W., Cornu D. \& Halpin C. 2002: Field and pulping performances of transgenic trees with altered lignification. - Nat. Biotechnol. 20: 607-612.

Pohjola M. 1947: Orgyia antiqua L. (Lepidoptera: Lymantriidae) mustikan tuholaisena. [Orgyia antiqua L. (Lepidoptera: Lymantriidae) as a pest of blueberry.] - Ann. Entomol. Fenn. 13: 22-23 [in Finnish].

Poupin M.J. \& Arce-Johnson P. 2005: Transgenic trees for a new era. - Vitro Cell Dev. Biol. Plant 41: 91-101.

Price P.W. 1997: Insect Ecology. 3rd ed. Wiley \& Sons, New York, pp. 271-281.

Ralph S., Oddy C., Cooper D., Yueh H., Jancsik S., Kolosova N., Philippe R.N., Aeschliman D., White R., Huber D., Ritland C.E., Benoit F., Rigby T., Nantel A., Butterfield Y.S.N., Kirkpatrick R., Chun E., Liu J., PalmQuist D., Wynhoven B., Stott J., Yang G., Barber S., Holt R.A., Siddiqui A., Jones S.J.M., Marra M.A., Ellis B.E., Douglas C.J., RitLAND K. \& Bohlmann J. 2006: Genomics of hybrid poplar (Populus trichocarpa deltoides) interacting with forest tent caterpillars (Malacosoma disstria): normalized and fulllength cDNA libraries, expressed sequence tags, and a cDNA microarray for the study of insect-induced defences in poplar. - Mol. Ecol. 15: 1275-1297.

Rao R., Fiandra L., Giordana B., de Eguileor M., Congiu T., Burlini N., Arciello S., Corrado G. \& Pennacchio F. 2004: AcMNPV ChiA protein disrupts the peritrophic membrane and alters midgut physiology of Bombyx mori larvae. Insect Biochem. Mol. Biol. 34: 1205-1213.

REAVEY D. 1991: Do birch-feeding caterpillars make the right feeding choices? - Oecologia 87: 257-264.

Regev A., Keller M., Strizhov N., Sneh B., Prudovsky E., Chet I., Ginzberg I., Koncz- Kalman Z., Koncz C., Schell J. \& ZilbersteIn A. 1996: Synergistic activity of a Bacillus thuringiensis delta-endotoxin and a bacterial endochitinase against Spodoptera littoralis larvae. - Appl. Environ. Microb. 62: 3581-3586.

Ruonala R., Rinne P.L.H., Baghour M., Moritz T., Tuominen H. \& KANGASJÄRVI J. 2006: Transitions in the functioning of the shoot apical meristem in birch (Betula pendula) involve ethylene. - Plant J. 46: 628-640.

Saguez J., Hainez R., Cherqui A., Wuytswinkel O. Van, JeanpIerre H., Lebon G., Noiraud N., Beaujean A., Jouanin L., Laberche J.-C., Vincent C. \& Giordanengo P. 2005: Unexpected effects of chitinases on the peach-potato aphid (Myzus persicae Sulzer) when delivered via transgenic potato plants 
(Solanum tuberosum Linné) and in vitro. - Transgenic Res. 14: 57-67.

Schuler T.H., Poppy G.M., Kerry B.R. \& Denholm I. 1998: Insect-resistant transgenic plants. - Trends Biotechnol. 16: $168-175$.

SCRIBER J.M. \& SLANSKY F. JR. 1981: The nutritional ecology of immature insects. - Annu. Rev. Entomol. 26: 183-211.

Seppänen E.J. 1970: The Food Plants of Finnish Macrolepidopterans. WSOY, Porvoo-Helsinki, 179 pp. [in Finnish].

Stout M.J., Thaler J.S. \& Thomma B.P.H.J. 2006: Plantmediated interactions between pathogenic microorganisms and herbivorous arthropods. - Annu. Rev. Entomol. 51: 663-689.

Suomela J., Kaitaniemi P. \& Nilson A. 1995: Systematic within-tree variation in mountain birch leaf quality for a geometrid, Epirrita autumnata. - Ecol. Entomol. 20: 283-292.

Thomas A.T. \& HodKINSON I.D. 1991: Nitrogen, water stress and the feeding efficiency of lepidopteran herbivores. $-J$. Appl. Ecol. 28: 703-720.

Timonen H., Aronen T., Laakso T., Saranpää P., Chiang V., Ylioja T., Roininen H. \& HägGman H. 2005: Does lignin modification affect feeding preference or growth performance of insect herbivores in transgenic silver birch (Betula pendula Roth). - Planta 222: 699-708.

Valenzuela S., Balocchi C. \& Rodriguez J. 2006: Transgenic trees and forestry biosafety. - Electron. J. Biotechn. 9: 334-339.

Vauramo S., Pasonen H.-L., Pappinen P. \& Setälä H. 2006: Decomposition of leaf litter from chitinase transgenic silver birch (Betula pendula) and effects on decomposer populations in a field trial. - Appl. Soil Ecol. 32: 338-349.
Vihervuori L., Pasonen H.-L. \& LyytikäInen-SaArenmaA P. 2008: Density and composition of an insect population in a field trial of chitinase transgenic and wild-type silver birch (Betula pendula) clones. - Environ. Entomol. 37: 1582-1591.

WALDBAUER G.P. 1968: The consumption and utilization of food by insects. - Adv. Insect Physiol. 5: 229-288.

WALLING L.L. 2000: The myriad plant responses to herbivores. - J. Plant Growth Regul. 19: 195-216.

Wang J., Chen Z., Du J., Sun Y. \& Liang A. 2005: Novel insect resistance in Brassica napus developed by transformation of chitinase and scorpion toxin genes. - Plant Cell Rep. 24: 549-555.

Wang Z., Xue Z., Fan H. \& Zhan Y. 2007: Resistance of transgenic Betula platyphylla to the defoliator Lymantria dispar. - Sci. Silv. Sin. 43: 116-120.

Wratten S.D., Edwards P.J. \& Dunn I. 1984: Wound-induced changes in the palatability of Betula pubescens and B. pendula. - Oecologia 61: 372-375.

Wu G., Chen F.J., Ge F. \& Xiao N.-W. 2011: Impacts of elevated $\mathrm{CO}_{2}$ on expression of plant defensive compounds in Bttransgenic cotton in response to infestation by cotton bollworm. - Agric. For. Entomol. 13: 77-82.

Yang M.S., Lang H.Y., GaO B.J., Wang J.M. \& Zheng J.B. 2003: Insecticidal activity and transgene expression stability of transgenic hybrid poplar clone 741 carrying two insectresistant genes. - Silvae Genet. 52: 5-6.

Zhu Q., Arakanea Y., Beeman R.W., Kramera K.J. \& MuthuKRISHNAN S. 2008: Characterization of recombinant chitinaselike proteins of Drosophila melanogaster and Tribolium castaneum. - Insect Biochem. Mol. Biol. 38: 467-477.

Received March 5, 2012; revised and accepted October 22, 2012 